\title{
AN EVALUATION OF PRIMARY COOPERATIVE AGRICULTURAL AND RURAL DEVELOPIMENT BANKS IN MYSURU AND IMANDYA DISTRICTS.
}

KEY WORDS: Cooperative, Bank, Agriculture, Rural and Growth
M. Visweswaraiah* Dr. S. Mahendrakumar
M.A, B.Ed Research Scholar DOS in Economics and Co-operation Manasagangothri, University of Mysore, Mysuru. *Corresponding Author

Professor (Retd.) DOS in Economics and Co-operation Manasagangotri, University of Mysore,Mysuru.

The cooperative banking sector plays an important role in providing credit to the agricultural sector in Karnataka. Especially, PCARD Banks with the wide network of their branches at the grass-root levels and vast experience in the field of Long Term Credit helped in transferring latest technology to the small farmers. The main intention of this study is to measure the performance of PCARD Banks in Mandya and Mysuru districts comparing with the help of secondary data and also the study made use of the exponential growth model to measure the performance of the banks. It is found from the analysis that, Mandya PCARD banks are well equipped with members' growth, share, and working capitals but Mysuru PCARD banks are performing well in terms of deposits, investments, and net profits when compared to Mandya district. There is need for proper loan recovery regulation through government intervention to overcome losses in PCARD Banks especially in Mandya District.

\section{INTRODUCTION:}

The cooperative banking sector plays an important role in providing credit to the agricultural sector. The structure of the cooperative banking sector in India is twofold. The urban areas are served by urban co-operative banks and the rural areas are served by two distinct sets of institutions extending short-term and long-term credit. The short-term co-operative credit institutions have a three-tier structure comprising State cooperative banks at the apex level, district central cooperative banks at the intermediate level, and primary agricultural societies at the base level. The long-term cooperative credit institutions have, generally, a two-tier structure comprising the State Co-Operative Agriculture and Rural Development Banks (SCARD Banks) at the state level and Primary Co-Operative Agricultural and Rural Development Banks (PCARD Banks) at Taluk or Block level. The Long-Term Cooperative Credit Structure consists of 20 State Co-operative Agriculture and Rural Development Banks and 697 Primary Co-operative Agriculture and Rural Development Banks. The PCARDBs are required to meet all the long-term credit needs of the farmers. Generally, these Banks are formed to free the weaker sections and farmers of Banks from economic exploitation. For example, poor farmers start cooperative credit societies to get loans at a lower rate of interest and to free themselves from money lenders.

\section{PCARDBs in Karnataka:}

Karnataka has the distinction of being the pioneer state in establishing the first co-operative credit society in Dharwad (at present Gadag District) District in 1905. The state has since then witnessed tremendous growth in the cooperative field.

Initial name is The Mysore Central Land Mortgage Bank (Present Name :The Karnataka State Co-operative Agricultural and Rural Development Bank (KSCARD Bank) was established in Karnataka on 25-11-1929 under the chairmanship of Sri Sreenivaslyengar as its first chairman. The exploitation of farmers by private Money Lenders was a challenge at the beginning of the 20th Century. The establishment of this Bank was one of the important steps in the eradication of this social evil. So as to follow that, the first Primary Co-operative Land Mortgage Bank was started at Bhimanakone, shivamoga district on 7th October 1930 Recommended by the Malenadu Abhirudhi Committee of Mysore Provience.

KSCARD Bank is an institution handling matters concerning policy, planning and operations in the field of Long Term Credit for Agricultural Development and for other economic and developmental activities in rural areas. Essentially, it is a refinancing agency for financial institutions offering production credit and investment credit for promoting agriculture and developmental activities in rural areas. It is a challenging task to strengthen rural people economically. The Government alone cannot make sea changes in rural parts where poverty is hindering the development process. Concerted efforts of cooperative societies in eliminating poverty and strengthening rural people emerged as unique alternatives for the development.

Primary Co Operative Agricultural Rural Development Banks are disbursing the Long Term Loans for variety of performance, such land leveling, Land wire fencing, digging, borewell, buying agri-accruements. Since most of the small and marginal farmers do not have is especially to long term credit primary cooperative agriculture and rural development banks have been playing a vital role.

The Karnataka State Cooperative Agriculture and Rural Development Bank have been established with a mission to encourage rural farmers to make adequate investments in agriculture by availing the benefit of its loan schemes. Infect, the back has been successful in preventing farmers from taking help of money lenders/ an account of availability of long term credit by PCARDS Banks, the farmers have been able to invest huge sum of money in agriculture. In Karnataka, the growth of PCARD Banks in Mysuru and Mandya districts is very dynamic and has significant contribution to the agriculture sector. Therefore, the present study has been made an attempt to measure the growth and performance of the PCARD Banks comparatively in both the districts.

\section{OBJECTIVE AND METHODOLOGY:}

The main objective of the present study is to measure the Performance of PCARD Banks in Mandya and Mysuru districts comparatively. For that, the study has made use of secondary data; the secondary data were collected from published articles, books, department of cooperation and annual progress reports of PCARD Banks for the year from 2010-11 to 2019-20.The results are obtained from the exponential growth model which is used to measure the performance of PCARD Banks and the various findings from secondary data have been summarized in this study.

Performance of PCARD Banks in Mandya and Mysuru Districts:

The significance of Agricultural growth and development is anxious on the ground that a sustained growth rate in 
Agricultural output is not only a strong anti-inflationary force but also makes a complementary impact on income growth. Facilitating the financial requirement for the purpose of boosting agriculture growth is a very necessary need of an economy. In order to meet this requirement, the Primary Cooperative Agriculture and Rural Development Bank are established in every Taluk to meet the long-term and shortterm financial requirements of the farmers. These banks are granting both agricultural and non-agricultural loans to farmers. This credit enables the farmers to enhance farm productivity with the use of modern technology in agriculture and the allied sector. This contributes to the increase in farm credit. The performance of these banks is more crucial and has a significant influence on agriculture development. Therefore, an attempt is made to evaluate the performance of PCARD Bank comparatively between Mysuru and Mandya districts.
The performance of the Primary Co Operative Agriculture and Rural Development Banks in terms of the total number of members, share capital, deposits, working capital, investments, borrowings, total borrowings, net profits, and accumulated loss of the banks in both Mysuru and Mandya districts for the year from 2010-11 to 2019-20 is presented in table 1. As per the given table, except for the total number of members, share capital, and working capital, Mysuru district has dominated in all the performances when compared to Mandya, and most importantly, the total accumulated loss is also high in Mandya than Mysuru. Therefore, in order to measure the annual growth of all the above variables comparatively between both districts, the study has made use of the exponential growth model to measure their performance over the period of time.

The results and the discussion is mentioned in the following section.

Table 1: Performance of PCARD Banks in Mandya and Mysuru Districts

(Rs in Lakh)

\begin{tabular}{|c|c|c|c|c|c|c|c|c|c|c|c|c|c|c|c|c|}
\hline & \multicolumn{2}{|c|}{ Members } & \multicolumn{2}{|c|}{ Share Capital } & \multicolumn{2}{|c|}{ Deposits } & \multicolumn{2}{|c|}{$\begin{array}{l}\text { Working } \\
\text { Capital }\end{array}$} & \multicolumn{2}{|c|}{ Investments } & \multicolumn{2}{|c|}{ Barrowings } & \multicolumn{2}{|c|}{ Net Profit } & \multicolumn{2}{|c|}{$\begin{array}{c}\text { Accumulated } \\
\text { Loss }\end{array}$} \\
\hline Year & Mandya & Mysuru & $\begin{array}{c}\text { Mandy } \\
\text { a }\end{array}$ & Mysuru & $\begin{array}{c}\text { Mandy } \\
\text { a }\end{array}$ & Mysuru & $\begin{array}{c}\text { Mandy } \\
\text { a }\end{array}$ & Mysuru & $\begin{array}{c}\text { Mandy } \\
\text { a }\end{array}$ & Mysuru & $\begin{array}{c}\text { Mandy } \\
\text { a }\end{array}$ & Mysuru & $\begin{array}{c}\text { Mandy } \\
\text { a }\end{array}$ & Mysuru & $\begin{array}{c}\text { Mandy } \\
\text { a }\end{array}$ & Mys \\
\hline \begin{tabular}{|c|}
$2009-$ \\
10
\end{tabular} & 47,332 & 1,364 & 374.58 & 354.49 & 0.19 & 7.45 & \begin{tabular}{|c|}
4455.5 \\
0
\end{tabular} & $\begin{array}{c}5161.5 \\
4\end{array}$ & 200.26 & 242.23 & 554.47 & 543.08 & 9.33 & 2.16 & 745.55 & $\begin{array}{c}185.4 \\
0\end{array}$ \\
\hline \begin{tabular}{|c|}
$2010-$ \\
11 \\
\end{tabular} & ,723 & 195 & 0.54 & 7.57 & 8.58 & 8.32 & \begin{tabular}{|c|}
5072.3 \\
9 \\
\end{tabular} & $\begin{array}{c}5072.3 \\
9\end{array}$ & 217.43 & 36 & $\begin{array}{c}1036.7 \\
1\end{array}$ & 87 & 49.20 & 2.21 & 65 & $\begin{array}{c}153.3 \\
0\end{array}$ \\
\hline \begin{tabular}{|c|}
$2011-$ \\
12 \\
\end{tabular} & 9,137 &, 943 & 1.33 & 2.51 & 22.54 & 9.28 & \begin{tabular}{|c|}
4829.4 \\
9
\end{tabular} & $\begin{array}{c}4829.4 \\
9\end{array}$ & 253.26 & 3.92 & 916.45 & $\begin{array}{c}1226.3 \\
3\end{array}$ & - & 5.78 & 0.96 & $\begin{array}{c}1154.1 \\
0\end{array}$ \\
\hline \begin{tabular}{|c|}
$2012-$ \\
13
\end{tabular} & 51,001 &, 577 & 97.66 & 3.05 & 44.82 & 9.33 & $\begin{array}{c}5631.7 \\
4\end{array}$ & $\begin{array}{c}4903.6 \\
6\end{array}$ & 260.75 & .86 & $\begin{array}{c}1090.4 \\
9\end{array}$ & 547.63 & 14.64 & 1.61 & $\begin{array}{c}1044.1 \\
8\end{array}$ & $\begin{array}{c}294.3 \\
0\end{array}$ \\
\hline \begin{tabular}{|c|}
$2013-$ \\
14 \\
\end{tabular} &, 454 & ,934 & 1.43 & 7.02 & 137.23 & 218.65 & $\begin{array}{c}5423.8 \\
0\end{array}$ & $\begin{array}{c}5003.2 \\
7\end{array}$ & 286.68 & .84 & $\begin{array}{c}1274.9 \\
4\end{array}$ & 725.48 & 28.01 & 5.90 & $\begin{array}{c}1058.3 \\
1\end{array}$ & $\begin{array}{c}330.0 \\
0\end{array}$ \\
\hline \begin{tabular}{|c|}
$2014-$ \\
15 \\
\end{tabular} & ,288 & 482 & 34.63 & .29 & 184.21 & 266.81 & \begin{tabular}{|c|}
7474.3 \\
3 \\
\end{tabular} & \begin{tabular}{|c|}
5517.5 \\
4 \\
\end{tabular} & 38.20 & 353.66 & \begin{tabular}{|c|}
1725.4 \\
2 \\
\end{tabular} & $\begin{array}{c}1225.9 \\
9 \\
\end{array}$ & - & 9.61 & \begin{tabular}{|c}
1285.3 \\
8 \\
\end{tabular} & $\begin{array}{c}1257.5 \\
0 \\
\end{array}$ \\
\hline \begin{tabular}{|c|}
$2015-$ \\
16
\end{tabular} &, 587 & 663 & 55.81 & .96 & 258.71 & 257.54 & $\begin{array}{c}8572.8 \\
0\end{array}$ & $\begin{array}{c}6347.0 \\
7\end{array}$ & 489.60 & 571.05 & $\begin{array}{c}2057.8 \\
2\end{array}$ & \begin{tabular}{|c|}
1034.1 \\
5
\end{tabular} & 61.24 & 4.73 & $\begin{array}{c}1305.7 \\
6\end{array}$ & $\begin{array}{c}1446.5 \\
0\end{array}$ \\
\hline \begin{tabular}{|c|}
$2016-$ \\
17 \\
\end{tabular} &, 957 & 3,700 & 32.15 & 2.01 & 598.84 & 40.44 & $\begin{array}{c}8752.5 \\
3\end{array}$ & $\begin{array}{c}6355.2 \\
3\end{array}$ & 568.00 & 696.73 & $\begin{array}{c}1849.0 \\
7\end{array}$ & \begin{tabular}{|c|}
1715.2 \\
2
\end{tabular} & $\begin{array}{ll}- & \text { - }\end{array}$ & - & $\begin{array}{c}1956.3 \\
4\end{array}$ & $\begin{array}{c}1667.0 \\
0\end{array}$ \\
\hline \begin{tabular}{|c|}
$2017-$ \\
18
\end{tabular} &, 680 & 1,019 & 04.96 & 6.18 & 235.30 & 460.70 & $\begin{array}{c}9583.6 \\
4\end{array}$ & $\begin{array}{c}7317.1 \\
4\end{array}$ & 844.41 & 694.93 & $\begin{array}{c}1361.4 \\
9\end{array}$ & 692.80 & - & 9.72 & $\begin{array}{c}2469.3 \\
4\end{array}$ & $\begin{array}{l}994.9 \\
7\end{array}$ \\
\hline \begin{tabular}{|c|}
$2018-$ \\
19
\end{tabular} & 62,178 & 5,054 & 973.89 & 626.10 & 219.41 & 493.01 & $\begin{array}{c}9826.6 \\
5\end{array}$ & $\begin{array}{c}7937.0 \\
9\end{array}$ & 928.39 & 949.99 & 453.03 & $\begin{array}{c}1050.0 \\
9\end{array}$ & - & - & $\begin{array}{c}3164.2 \\
5\end{array}$ & $\begin{array}{c}327.0 \\
0\end{array}$ \\
\hline \begin{tabular}{|c|}
$2019-$ \\
20 \\
\end{tabular} & 63,075 & 35,769 & 60.50 & 618.77 & 258.51 & 543.95 & $\begin{array}{c}9101.1 \\
6\end{array}$ & \begin{tabular}{|c|}
8226.0 \\
4 \\
\end{tabular} & 992.44 & $\begin{array}{c}1075.7 \\
3\end{array}$ & 358.53 & 924.79 & 15.09 & - & $\begin{array}{c}3721.9 \\
2\end{array}$ & $\begin{array}{c}679.9 \\
0 \\
\end{array}$ \\
\hline
\end{tabular}

\section{Source: PCARD Banks, Annual Reports}

\section{RESULTS AND DISCUSSION:}

PCARD Banks with the wide network of their branches at the grass-root level and vast experience in the field of rural credit can help in transferring modern technology to the small farmers and rural artisans at minimum cost, thereby bringing about rural development. It is very necessary to evaluate the performance of PCARD Banks in terms of the growth of members, capital, deposits, loans and advances, profit, loss, and total NPA of the Bank comparing between Mandya and Mysuru Districts. Here the study has used the Exponential Growth Model to measure the growth and performance of PCARD Banks in both Mysuru and Mandya Districts. The results and discussion of the performance of PCARD Banks in both Mysuru and Mandya Districts are presented in the table below.

Table 2: Performance of PCARD Banks in Mandya and Mysuru Districts

\begin{tabular}{|c|l|c|c|c|c|}
\hline \multicolumn{2}{|c|}{ Dependent variable } & Constant & $\begin{array}{c}\text { R } \\
\text { Square }\end{array}$ & $\begin{array}{c}\text { Parameter } \\
(\beta 1)\end{array}$ & Sig. \\
\hline \multirow{2}{*}{ Members } & Mandya & 46392.855 & .825 & .039 & .000 \\
\cline { 2 - 6 } & Mysuru & 29232.815 & .701 & .020 & .003 \\
\hline \multirow{3}{*}{ Share capital } & Mandya & 373.058 & .947 & .105 & .000 \\
\cline { 2 - 6 } & Mysuru & 302.595 & .916 & .078 & .000 \\
\hline \multirow{2}{*}{$\begin{array}{c}\text { Working } \\
\text { Capital }\end{array}$} & Mandya & 4427.854 & .873 & .088 & .000 \\
\cline { 2 - 6 } & Mysuru & 4225.034 & .912 & .065 & .000 \\
\hline
\end{tabular}

\begin{tabular}{|c|l|c|c|c|c|}
\hline \multirow{2}{*}{ Deposits } & Mandya & 15.936 & .695 & .361 & .003 \\
\cline { 2 - 6 } & Mysuru & 12.966 & .746 & .445 & .001 \\
\hline Investments & Mandya & 157.880 & .959 & .188 & .000 \\
\cline { 2 - 6 } & Mysuru & 159.689 & .905 & .191 & .000 \\
\hline Borrowings & Mandya & 1596.809 & .147 & -.073 & .273 \\
\cline { 2 - 6 } & Mysuru & 739.692 & .108 & .039 & .355 \\
\hline \multirow{2}{*}{ Net Profit } & Mandya & 48.101 & .593 & .265 & .009 \\
\cline { 2 - 6 } & Mysuru & 10.055 & .576 & .392 & .011 \\
\hline \multirow{2}{*}{$\begin{array}{c}\text { Accumulated } \\
\text { Loss }\end{array}$} & Mandya & 555.798 & .963 & .183 & .000 \\
\cline { 2 - 6 } & Mysuru & 932.397 & .894 & .094 & .000 \\
\hline
\end{tabular}

\section{Source: Computed by Author}

The results of the exponential growth model are reported in table 2. As per the given results, the average annual growth of members in Mandya is 3.9 percent which is statistically significant at $l$ percent level with the $R$ square value of 0.825 . Whereas the average annual growth of members in Mysuru is 2 percent which is also statistically significant at 1 percent level with the $\mathrm{R}$ Square value 0.701 . Similarly, the average annual growth of share capital in Mandya PCARD banks is 10.5 percent which is statistically significant at 1 percent level with the R Square value of 0.947. Whereas in Mysuru it is 7.8percent which is statistically significant at 1 percent level with the $R$ Square value of 0.916 . Likewise, the average annual growth of working capital in Mandya PCARD banks is 8.8percent which is statistically significant at 1 percent level. Whereas in Mysuru it is 6.5 percent which is also statistically significant at 
a 1 percent level with the $R$ Square value of 0.912 . Subsequently, the average annual growth of deposits in Mandya PCARD banks is 36.1 percent which is statistically significant at a 1 percent level with the $R$ square value of 0.69 , whereas for Mysuru it is 44.5percent which is also statistically significant at 1 percent level with the R Square value of 0.746 . With regard to Investments, the average annual growth of investment in Mandya PCARD banks is 18.8 percent which is statistically significant at 1 percent level with the R Square value of 0.959 , whereas for Mysuru it is 19.1 percent which is also statistically significant at 1 percent level with the R Square value of 0.905 . The average annual growth of borrowings in Mandya PCARD banks is negative which is also statistically insignificant, whereas in Mysuru district it is 3.9 percent but it is also statistically insignificant. Further, the average annual growth of net profit in Mandya is 26.5 percent which is statistically significant at 1 percent level with the R Square value of 0.593 , whereas the average annual growth of net profit in Mysuru PCARD banks is 39.2 percent which is also statistically significant at 5 percent level with the R Square value of 0.576. Lastly, the average annual growth of accumulated loss in Mandya PCARD banks is 18.3percent which is also statistically significant at 1 percent level with the $\mathrm{R}$ Square value of 0.963 , whereas in Mysuru PCARD banks, the average annual growth of accumulated loss is 9.4 percent which is also statistically significant at 1 percent level with the $\mathrm{R}$ Square value of 0.894

It is clearly revealed from the above analysis that, both Mysuru and Mandya PCARD Banks are playing a vital role in providing financial assistance by way of Long Term Loans for various agricultural activities. The performances are concerned; the PCARD banks in Mandya district have significant growth in terms of members, share capital and also working capital when compared to Mysuru. But the Mysuru PCARD banks, though there is no enough growth in terms of members, share capital and also working capital, the banks at Mysuru have registered a tremendous growth in terms of deposits, investments and net profits when compared to Mandya district. Overall, Mysuru district PCARD banks are performing well in respect major variables like deposits, investment and profit.

\section{CONCLUSION}

The co-operative banking sector plays an important role in providing credit to the agricultural sector is respect of Long term Loans in Karnataka. Especially, PCARD Banks with the wide network of activities in all taluks at the grass-root levels and vast experience in the field of rural credit helps in transferring latest technology to the small farmers. The PCARD Banks located is Mysuru and Mandya district are emerging institutions in accessing the financial assistance to this primary sector. Hence, an attempt has been made to measure the performance of both districts in terms of members, share capital, working capital, deposits, investments, borrowing, net profit, and accumulated loss. It is clearly revealed from the above analysis that, the PCARD Banks in Mandya district have registered a notable growth in terms of members, share capital, and also working capital when compared to Mysuru. But the Mysuru PCARD Banks, though there is not enough growth in terms of members, share capital, and also working capital, have positive growth in respect of deposits, investments, and net profits when compared to Mandya district. Overall, Mysuru district PCARD Banks is performing well if we take into consideration of the major variables like deposits, investment, and profit. Since the PCARD banks in Mandya are running under low-profit status though the percentage of share capital and working capital is high, there is a need for proper loan recovery regulation in a better performance.

\section{REFERENCES}

1. Harisha, B. N. (2018). Performance of primary co-operative agriculture and rural development banks in Karnataka. International Journal of Advanced Educational Research. ISSN: 2455-6157, Impact Factor: RJIF 5.12,
www.educationjournal.org,Volume 3; Issue 2; March 2018; Page No.70-73.

2. Gopalakrishna K. and Pramod Gonchkar. (2018). Impact of Primary CoOperative Agriculture And Rural Development Bank Credit On SocioEconotion Economic Development OfFarmers Astudy Wr District Of Karnataka. IJEMR - May 2018 - Vol 8 Issue 05 - Online - ISSN 2249-2585 Print - ISSN 2249-8672 1 www.ijemr.in

3. Kammar Sakrappa, And Shanumugam, N. (2019). Study on Financial Analysis of Primary Co-Operative Agriculture and Rural Development Banks (PCARDBS) In Karnataka. The International journal of analytical and experimental modal analysis, Volume XI, Issue X, Pp 28-38, October/2019, ISSNNO:0886-9367.

4. Nagi Reddy, K and Chandraiah, M. (2019).Progress of Cooperative Banks in India.International Journal of Engineering and Management Research, eISSN: 2250-0758 | p-ISSN: 2394-6962, Volume- 9, Issue- 2 (April 2019), www.ijemr.nethttps://doi.org/10.31033/ijemr.9.2.06

5. Rajakrishnan, V.S. Rajeswari, P. and Kaliyaperumal,N.A Study on Land Development Banks (LDB) - Banking \& Credit. IOSR Journal of Business and Management (IOSR-JBM), e-ISSN: 2278-487X, p-ISSN: 2319-7668, PP 44-52, www.iosrjournals.org

6. ShivakumaraS, and Manjunath T. R. (2016). Performance of primary cooperative agriculture and rural development banks in Karnataka. ISSN: 2349-4182, Print ISSN: 2349-5979, Impact Factor: RJIF 5.72, www.allsubjectjournal.com, Volume 3; Issue 11 ; November 2016; Page No.3941 